\title{
A TANÁRI KOMPETENCIASZINTEK KIDOLGOZÁSA, AZAZ A SZTENDERDEK KIDOLGOZÁSA
}

\author{
NYIKOS MÁRTA \\ az Eötvös Loránd Tudományegyetem Neveléstudományi Doktori Iskolájának \\ hallgatója \\ nyikos.marti@freemail.hu
}

„A pedagógussá válás és a szakmai fejlődés sztenderdjei” címet viselő kötet egy széleskörü, átfogó kutatás eredményeképpen jött létre. Az elkészült tanulmány nem csak a tanárképzés során elérendő sztenderdeket tartalmazza, hanem ezeket egy olyan rendszerbe kívánja illeszteni, amely támpontot adhat a pedagógusok szakmai fejlődéséhez és a remélhetőleg megvalósuló pedagógus-pályamodell egyes szintjein való elörelépéshez.

Napjainkban a kompetenciafogalom, a kompetencia alapú tanárképzés és az ehhez szorosan kötődő sztenderdek oly sokat emlegetett fogalmak, hogy pontos jelentésük, funkciójuk sokszor háttérbe szorulhat, mert már automatikusan használjuk őket. Ezért az elméleti tisztázás nélkülözhetetlen.

A tanári hivatás képesítési követelményeit kompetenciák formájában fogalmazzák meg. Ezek a kompetenciák - a leginkább elterjedt meghatározás szerint - a szakmai felkészültség összetevőit jelentik, magukba foglalják a tudást, az attitüdöket/nézeteket és a képességeket. A képesítési követelményekkel szemben sokféle kívánalmat támaszthatunk, de ezek közül talán a leglényegesebb az, hogy mérhetök legyenek (Falus, 2005). Ennek a feltételnek tesznek eleget a sztenderdek, amelyek a kompetenciák mérhető változatai. Hasonlóan a kompetencia fogalmához, a sztenderdek értelmezésére is sokféle definíció született. Ezek közül az egyik legismertebb a következő. Az angol Teacher Training Agency (TTA) meghatározása szerint: „A sztenderdek a kompetenciák szintjeit fogalmazzák meg, s kellően specifikusak, explicitek és értékelhetők, világos alapot szolgáltatnak a képesítés megbízható, konzisztens odaítéléséhez függetlenül attól, hogy a tanárjelölt milyen képző intézményben szerezte tudását." (TTA, 1998, 1. o.)

Mindezek után és még a kötet ismertetése előtt sokunkban felmerülhet a kérdés, hogy tulajdonképpen mire is alkalmasak a sztenderdek a gyakorlatban? Segítségükkel egyfelöl megvalósulhat az a célkitüzés, hogy tényleges, autentikus tanítási helyzetekben lehessen megragadni a tanárok, tanárjelöltek tudását, egy adott szituációban a döntéseit, gondolkodását. Mivel a sztenderdekben ötvözötten jelennek meg a szaktárgyi, pedagógiai, pszichológiai, szakmódszertani ismeretek, és ezáltal a tanári tevékenységben realizálódó képességeket írják le, a sztenderdek hasz- 
nálata, teljesítése egy komplex ismeretrendszert feltételez (Falus, 2006). Ez utóbbi - véleményem szerint is - a sztenderdek egyik legnagyobb előnye, mert a tanárjelöltek esetében sokszor hiányzik az ismeretek integrált alkalmazása.

A sztenderdek kidolgozása a Társadalmi Megújulás Operatív Program (TÁMOP) 13. alprojektjének - „,Módszertani sztenderdek kidolgozása a pedagógusjelöltek pályaalkalmasságára és a képzés eredményességére irányuló kutatások” - keretében valósult meg. A projekt szakmai kivitelezésében több intézmény is részt vett, melyben a munkafolyamat zászlóshajója az egri Eszterházy Károly Föiskola volt. E kötet létrehozása tehát nem egy szerző, hanem egy munkacsoport feladata volt.

A 2011 öszén bemutatott kötet három fejezetből és egy jelentős terjedelmü, a könyv második részét képező Függelékből áll. Az első fejezetben a szerzők szakmai koncepciójával ismerkedhetünk meg. Ebben szó esik a sztenderdek kidolgozásáról; a tanári kompetenciák fejlődésének és a sztenderdek összefüggéseiről; az egyes tanári kompetenciaszintekröl; a sztenderdek értékeléséről; a sztenderdek és a pedagógusképzés kapcsolatáról; továbbá a sztenderdek és a pedagógus-pályamodell lehetőségeiről, legvégül pedig a könyv használatához kapunk további információkat és hasznos tanácsokat.

„A tanári kompetenciaszintek/sztenderdek kidolgozása” címet viselő első rész olyan alapfogalmakat tisztáz, mint tanári kompetencia, sztenderd, indikátor. Nagyon tömören, közérthetően megfogalmazott és példákkal illusztrált gondolatmenet vezeti el az olvasót az oly sokszor hallott és emlegetett tanári kompetencia fogalmától egészen a fejlettségi szintek eléréséig, illetve a tanári munka sztenderdek által történő értékeléséig. A továbbiakban arról olvasunk, hogy a sztenderdek tartalmi kidolgozásánál mire építettek a munkacsoport tagjai. A két legfontosabb dokumentum e szerint a tanárképzés képesítési és kimeneti követelményeit tartalmazó miniszteri rendelet [15/2006 (IV.3.)] valamint a 2006-ban az ELTE PPK-n megfogalmazott tanári kompetencialista. Mindemellett a munkához hozzájárultak különböző pedagóguskutatások eredményei, a nemzetközi tapasztalatok elemzése és nem utolsó sorban a munkacsoport tagjainak több évtizedes szakmai tapasztalatai.

A második rész talán még az előzőekben megfogalmazottnál is világosabban ad választ arra a kérdésre, milyen célt is szolgál a sztenderdek kidolgozása: ,, a sztenderdek a folyamatos szakmai fejlödés/fejlesztés során elérendö célokat fogalmazzák meg, s ezáltal segitik a tanárok egyéni szakmai fejlödési irányának meghatározását... A másik funkciójuk az, hogy a kompetenciák szintjeit... megállapithatóvá tegyék, és ezzel hozzájárulhatnak a pedagógus-pályamodell kidolgozásához is. " (7-8. o.)

A harmadik rész tárgyalja az egyes tanári kompetenciaszinteket és mutatja be azok fö jellemzőit. A szerzők a nyolc tanári kompetenciából kiindulva öt szintet állapítottak meg. Ezek a következők: 1. szint: a diplomás pedagógus, 2. szint: a véglegesített pedagógus, 3. szint: a tapasztalt pedagógus, 4. szint: a kiváló pedagógus, 5. szint: a mesterpedagógus. Fontos megemlítenünk, hogy felosztásuk alapján beik- 
tattak/létrehoztak ezen kívül egy ún. 0 . szintet is, amely a gyakorlatra bocsátás feltétele. Saját tapasztalataim is alátámasztják ennek a szükségességét, hiszen előfordul, hogy egy tanárjelölt tanulmányai befejezése után sem áll még készen az iskolai gyakorlat megkezdésére.

A negyedik részben fejtik ki a szerzők, hogy a sztenderdek értékelésekor milyen célkitüzésekkel számolhatunk. Ezek közé tartozik a tanári kompetenciák fejlettségének megítélése, illetve a szakmai kompetenciák fejlődésének értékelése. Hangsúlyozzák, hogy az egész szakmai fejlődési folyamatban nagyon fontos szerepet játszik az, hogy a tanárok, tanárjelöltek a saját teljesítményükre folyamatosan visszajelzéseket kapjanak és ők maguk is tudjanak az elvégzett munkára reflektálni. A könyv írói kiemelik, hogy ez a kötet éppen ebben kíván segítséget nyújtani azáltal, hogy az önreflexiók, visszajelzések, értékelések szempontjainak összeállításához mutatnak be példákat.

Az első fejezet ötödik és hatodik részei a sztenderdek pedagógusképzésben betöltött szerepével és jelentőségével, valamint azok hosszútávú hatásával foglalkozik. A kidolgozott sztenderdek egyik legnagyobb szerepe talán nyilvánul meg, hogy - és ez jelen kötet legnagyobb érdeme is egyben - a tanárképzés kimeneti követelményeinek meghatározásakor már nem csak a kompetenciák tartalmi leírását ismerjük, hanem a kompetenciák további szintekre bontását.

Ebben a fejezetben még szó esik a sztenderdek másik fontos feladatáról, a pedagógus-pályamodellben betöltött szerepéről. Általuk a pedagógusok szakmai fejlődése, előmenetele sokkal könnyebben megítélhető, és az egyéni szakmai fejlesztési terv szükség szerint tervezhető, meghatározható. A szerzők kihangsúlyozzák, hogy nagyon fontos lenne az, hogy a pályamodellt ne tekintsék egyenlönek a pedagógusok bérskálájával. Az előbbi ennél jóval többre hivatott. Remélhetőleg a pedagógustársadalom is elfogadja az ebben rejlő szakmai fejlődési lehetőségeket.

A kötet második fejezete az egyes tanári kompetenciák fejlődési folyamatát, a fejlődés szintjeit mutatja be. Itt a kompetenciák leírásának rövid változatát tekinthetjük át, úgy, hogy minden egyes kompetencia rövid tartalmi összefoglalása után az egyes szintekre ( $0-5$. szint) vonatkoztatott elemeit olvashatjuk.

A harmadik fejezet „A tanári teljesitmény sztenderd alapú értékelésének eszközei" címet viseli. Ebben a részben konkrét eszközöket mutatnak be a szerzök a nyolc tanári kompetencia sztenderdjeinek érékelésére. Az itt szereplő érékelő eszközökkel segítséget kívánnak adni ahhoz, hogy meg lehessen ítélni az adott szinten elérendő sztenderdek meglétét. A szerzők kiemelik, hogy ezeket az eszközöket nem tekintik kizárólagosnak, csak mintegy támpontot, kiindulópontot szeretnének nyújtani további hasonló eszközök - akár pedagógusközösségek által történő - kidolgozásához és természetesen alkalmazásához. A projekt keretében lezajlott fejlesztési periódusban az első három szint (a gyakorlatra bocsátás feltétele, a diplomás tanár szintje és a véglegesített tanár szintje) kidolgozására került sor. Az értékelés alapvető kritériumait, azaz indikátorait és módszereit részletesen mutatják be a szerzők 
és egy-egy, mind a nyolc kompetenciát felölelő szempontsort kínálnak a 0-1-2. szint sztenderdjeinek mérésére. Ezek az értékelőlapok használhatók a mentorok, vezetőtanárok által, illetve mintául szolgálnak az önértékeléshez és a tanulói reflexiókhoz.

A kötet második felét képezö Függelékben találkozhat az olvasó a tanári kompetenciák részletes leírásával, természetesen az egyes szintekhez kapcsolódóan. A szerzők kiemelik és bemutatják az értékelés eszközei közül a tanári gyakorlat teljes dokumentációját tartalmazó portfóliót, hiszen ezt az értékelési folyamatban valamennyi kompetencia esetében, valamennyi szinten fel lehet használni. Végül a Függelék utolsó részében példákat találunk az egyes kompetenciák fejlődését támogató értékelöeszközökre.

Meg kell említenünk, hogy a hazai sztenderdek, illetve sztenderdrendszer és a pedagógus-pályamodell kidolgozása elött sor került egy nemzetközi vizsgálatra, amely 10 ország tanárképzési rendszerét tárta fel. Ezeket a tapasztalatokat egy külön kötetben foglalták össze, mely a „Tanári pályaalkalmasság-kompetenciák-sztenderdek. Nemzetközi áttekintés” címmel jelent meg.

A fent bemutatott kötetet minden bizonnyal haszonnal forgathatják mindazok, akik a tanárképzés valamely területén érintettek, mint a tanárjelölt hallgatók, gyakorló pedagógusok és a képzésben résztvevő oktatók. A szerzők szándéka szerint a későbbiekben sor kerülne a további három szint - tapasztalt tanár, kiváló tanár, mester tanár - részletes feltárására és az értékelés módjainak kidolgozására, valamint az egész rendszer gyakorlatban történő kipróbálására. Remélhetőleg megvalósul ennek az eredményes kutató-fejlesztő munkának a folytatása.

Kotschy Beáta (2011, szerk.): A pedagógussá válás és a szakmai fejlődés sztenderdjei. Eszterházy Károly Föiskola, Eger, 184 oldal.

\section{Irodalom}

A tanárképzés képesítési követelményei ELTE PPK, 2006. (kézirat)

Falus Iván (2005): Képesitési követelmények - kompetenciák - sztenderdek. Pedagógusképzés, 1. sz. 1-16.

Falus Iván (2006): A tanári tevékenység és a pedagógusképzés új útjai. Műszaki Könyvkiadó, Budapest.

Falus Iván (2011, szerk.): Tanári pályaalkalmasság-kompetenciák-sztenderdek. Nemzetközi áttekintés. Eszterházy Károly Főiskola, Eger.

TTA (1998): National Standards for Qualified Teacher Status, Teacher Training Agency, London. 